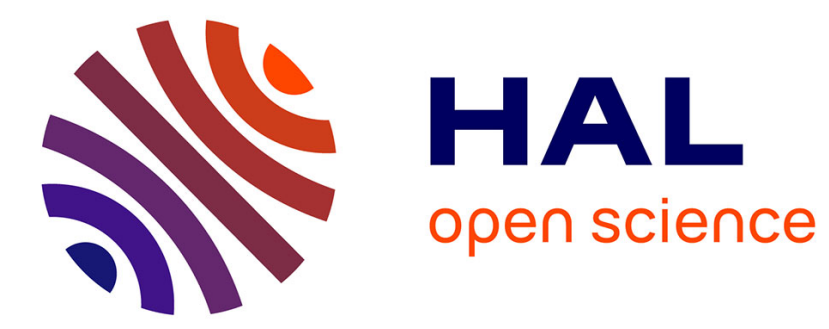

\title{
Dislocations in TiAl
}

G. Hug, A. Loiseau, P. Veyssière

\section{To cite this version:}

G. Hug, A. Loiseau, P. Veyssière. Dislocations in TiAl. Revue de Physique Appliquée, 1988, 23 (4), pp.673-674. 10.1051/rphysap:01988002304067300 . jpa-00245823

\section{HAL Id: jpa-00245823 https://hal.science/jpa-00245823}

Submitted on 1 Jan 1988

HAL is a multi-disciplinary open access archive for the deposit and dissemination of scientific research documents, whether they are published or not. The documents may come from teaching and research institutions in France or abroad, or from public or private research centers.
L'archive ouverte pluridisciplinaire HAL, est destinée au dépôt et à la diffusion de documents scientifiques de niveau recherche, publiés ou non, émanant des établissements d'enseignement et de recherche français ou étrangers, des laboratoires publics ou privés. 


\title{
DISLOCATIONS IN TIAI
}

\author{
G. Hug*, A. Loiseau*, P. Veyssière** \\ * ONERA, B.P. 72, 92322 Châtillon Cedex (France) \\ ** CNRS, same address
}

The L10 structure is a fcc related ordered phase under which TiAl crystallizes. The smallest Burgers vectors (BV) are the edges of the body centered tetragonal unit cell, i.e. [001], $1 / 2[110], 1 / 2[1 \overline{1} 0]$ in the cubic cell (fig. 1).

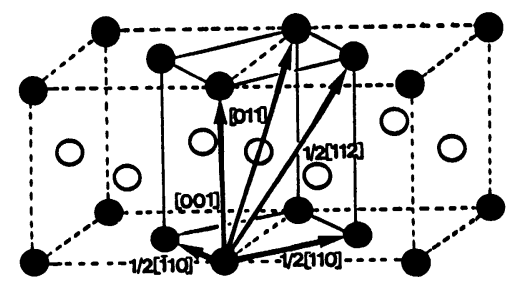

\section{Figure 1}

Whereas the $1 / 2\langle 110\rangle$ BVs are present at any temperature of deformation, [001] is only activated at very high temperature $\left(900-1000^{\circ} \mathrm{C}\right)$. At low and intermediate temperatures, the deformation is due to dislocations with larger BVs, i.e. $1 / 2\langle 112\rangle$ and 〈011〉, diagonal of the face and of the unit cell, respectively. These superdislocations dissociate in two superpartials with an antiphase boundary (APB) in between. Amongst the numerous possible dissociation schemes [1], some have been identified by weak-beam between 20 and $1000^{\circ} \mathrm{C}$.

- At room temperature [011] superdislocations are dissociated in a planar configuration according to (fig. 2) :
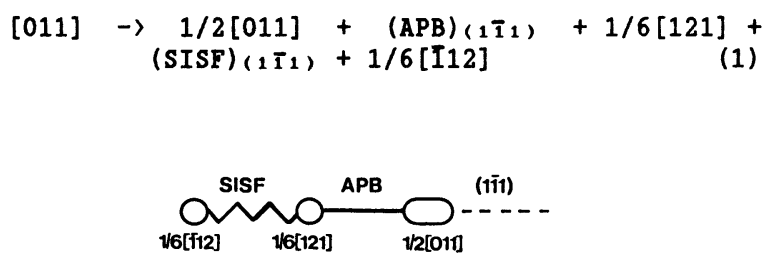

Figure 2

The screws are often found to decompose in order to give rise to $1 / 2\langle 112\rangle$ superdislocations :

[011] $\rightarrow 1 / 2[110]+1 / 2[\overline{1} 12]$

where the $1 / 2[112]$ is dissociated in the glide plane :

$1 / 2[112] \rightarrow 1 / 2[101]+(\mathrm{APB})\left(1 \overline{1}_{1}\right)+1 / 6[121]$

$$
+(\operatorname{SISF})\left(1 \overline{T_{1}}\right)+1 / 6[\overline{\mathrm{I}} 12]
$$

This configuration, however, is unstable, the $1 / 2$ [112] can dissociate by a cross-slip mechanism involving the (111) planes according to [2] :

$1 / 2[\overline{1} 12] \rightarrow 1 / 6[\overline{1} 12]+(\mathrm{SESF})+1 / 3[\overline{\mathrm{I}} 12]$

Since the $1 / 6[112]$ is spread over two consecutive atomic planes in order to give rise to the SESF, it is highly sessile, and it gives rise to faulted dipoles trailed by the $1 / 2\left[\mathrm{~T}_{12}\right]$ superdislocations [3].

- As the temperature of the deformation is raised up to $600^{\circ} \mathrm{C}$, the [011] superdislocations undergo a locking dissociation, which in turn induces an anomalous increase of the flow stress [4]. The dissociation reaction of the [011] screw superdislocations is similar to reaction (1) with the difference that the APB is now located in the (100) cube plane [5] (fig. 3) :

$[011] \rightarrow 1 / 2[011]+(\mathrm{APB})(100)+1 / 6[121]$

$+(\mathrm{SISF})\left(1 \mathrm{~T}_{1}\right)+1 / 6\left[\mathrm{~T}_{12}\right]$

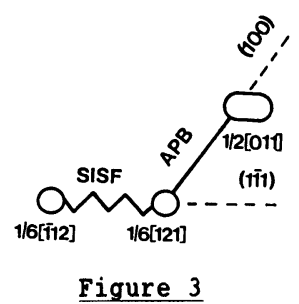

The three fold dissociated configuration is the analogous for L10 of the Kear-Wilsdorf model developped for $\mathrm{L1}_{2}$. When dissociated according to reaction (5), the [011] screw superdislocations have a lower energy than at won temperature (reaction (2)). The 1/2(112) superdislocations do not thus participate to the deformation.

At $800^{\circ} \mathrm{C}$, however, the Kear-Wilsdorf locks no more operate : the 〈011〉 superdislocations have completely disappeared and the $1 / 2\langle 112\rangle$ superdislocations are dissociated according to (4), but the $1 / 6[112]$ is glissile at that temperature.

- When deformation is conducted at higher temperature $\left(1000^{\circ} \mathrm{C}\right)$, the $1 / 2\langle 112\rangle$ dislocations are found to decompose according to : 
$1 / 2[\overline{1} 12] \rightarrow 1 / 2[\overline{1} 10]+[001]$

with the [001] dislocation moving in the (110) plane.

The dislocation behaviour $\perp$ TiAl is thus charac- terized by an evolution toward configurations of lowest energy, some of which are attained by a thermally-aided mechanism. These configurations are associated with small BVs, except in the domain of the flow stress peak.

\section{References}

[1]. GREENBERG, B.A., 1970, Phys. Stat. Sol., 42, 459 ; 1973, Phys. Stat. Sol. (b), 55, 59

[2]. HUG, G., LOISEAU, A., and LASALMONIE, A., 1986, Phil. Mag. A, 54, 47.

[3] . LIPSITT, H.A., SCHECHTMANN, D., and SCHAFRIK, R.E., 1975, Acta Metall., 33, 1355 .
[4]. KAWABATA, T., KANAI, T., and IZUMI, O., 1985, Acta Metall., 33, 1355.

[5]. HUG, G., LOISEAU, A., and VEYSSIERE, P., 1986, Proc. XIth Int. Cong. on Elect. Micr., Kyoto, 1575. 